\title{
The Role of Customer Relationship Management on Enhancing the Customers' Satisfaction in the Banks in Palestine
}

\author{
Raed A. M. Iriqat ${ }^{1} \&$ Mohannad A. M. Abu Daqar ${ }^{2}$ \\ ${ }^{1}$ Department of Business Administration, Faculty of Administrative and Financial Sciences, Arab American \\ University, Palestine \\ ${ }^{2}$ Master in Strategic Planning and Fundraising, Arab American University, Palestine \\ Correspondence: Raed A. M. Iriqat, Department of Business Administration, Faculty Administrative and \\ Financial Sciences. Arab American University, P. O. BOX 240, Jenin-West Bank, Palestine. Tel: \\ 970-595-386-355. E-mail: raed.iriqat@aauj.edu.
}

Received: October 29, 2017

Accepted: November 8, $2017 \quad$ Online Published: November 28, 2017

doi:10.5539/mas.v11n12p84

URL: https://doi.org/10.5539/mas.v11n12p84

\begin{abstract}
The aim of this paper is to investigate the role of customer relationship management on customers' satisfaction in the banks in Palestine. The primary data was collected from Palestinian Banking Employees. Based on the multiple regression analysis and person correlation tests, this paper finds these results that the regression indicated these two predictors: CRM system integration and Service quality explained $64.2 \%$ of the variance $\left(\mathrm{R}^{2}=0.642, \mathrm{~F}(5,223)=50.222, \mathrm{P}<0.05\right)$. The scholars' found that service quality significantly predicted customers' satisfaction $(\beta=.191=, p=0.001)$, as did CRM system integration $(\beta=.727=, p=0.000)$. In addition, study finds that there is a positive significant relationship between customer relationship management dimensions and customers satisfaction. Finally, this study recommended keeping the effective communication between CRM and the bank's customers.
\end{abstract}

Keywords: Customer Relationship Management, Customers' Satisfaction, North West Bank, Relationship Managers, Key Performance Indicator

\section{Background}

Customer relationship management (CRM) is a concept to manage the organization's interactions with its customers, users and all the issues related to sales and financial transactions. The technology in this regard used to manage and facilitate the organization's business processes and activities. Therefore, CRM considered as a strategic business and process rather than a technical issue (Dowling, 2002). Moreover, it's important to recognize that CRM has a long-term aim which is to enhance the quality and to improve the interface with the customers which lead toward customer satisfaction (Haridasan \& Venkatesh, 2011). For a successful CRM implementation, it's highly recommended and required the top management system commitment and vision. The policies of the strategy structure ought to be flexible and explicit especially the pricing policies. These aspects are key issues to increase the customers' satisfaction and the firm benefits (Khaligh et al. 2012).

Customer satisfaction is a marketing term that measures how products or services supplied by a company meet or surpass a customer's expectation. Customer satisfaction is important because it provides marketers and business owners with a metric that they can use to manage and improve their businesses. In a competitive marketplace where businesses compete for customers; customer satisfaction is seen as a key differentiator (Beard,2014). The importance of customer satisfaction in the banking industry can't be discarded while the satisfied customers were the free advertising tool for the company. It's crucial to put the customers' in at the center of the business in the banking industry because it's easier and more profitable to sell and serve present customers than finding new ones. The banks in Palestine are setting themselves strategies to ensure customer loyalty and satisfaction (Mohsan et al., 2011).The banks' vision is to achieve profitability and achieving a higher degree of customer satisfaction, and by measuring the current situation there is an enormous competition between these banks to gain more customers and to increase their market share in the local market in Palestine (Ismail et al, 2013). This study tries to address the role of Customer Relationship Management on customers' satisfaction in the banks in Palestine. 


\section{Literature Review}

Customer Relationship Management (CRM), according to Vella and Caruana (2012), involves the management of an organization's interactions with its customers through analysis of customer history data with the aim of enhancing business relationships with the organization's clients in order to improve customer retention rates. Peltier et al. (2013) further note that the CRM approach compiles customer data from various channels of communication including social media and customer feedback so as to learn about the customers' needs and how to satisfy these needs. Generally, CRM entails technologies, strategies, and practices used by organizations to analyze and manage their interaction with the customers across the entire lifecycle. Khodakarami and Chan (2014) point out that technologies used in CRM seek to automate processes in diverse areas such as management and analysis, customer support, marketing, and sales. Moreover, Baran and Galka (2013) define the basic dimensions of CRM as the formation and maintenance of mutual loyalty between customers and the company, constructing customer interaction, use of direct techniques of marketing, and customer relationship personalization. Basically, these principles are aimed at increasing the efficiency and reducing costs related to customer interactions; as well as improving labor efficiency and increasing decision-making speed.

CRM emerged as a crucial strategy to identify the banks profitable customers and prospects, also it enables the banks to dedicate time and attention to enhance the relationships with their clients through the customized services, re-pricing, discretionary decision-making, and marketing (Vella et al., 2012; Awasthi \& Sangle, 2013; Farquad et al., 2012). Moreover, Agariya and Singh (2012) showed that CRM aiding banks to differentiate customer segments based on profitability and business besides to identifying the related risks with loan clients, customers mostly like to leave banks and responding to other available offers from competitors. CRM plays a significant role in the banking industry by aiding banks to capture the customer's data and to enhance the accessibility of customer information, so it enables bank branches to improve their corporate identity.

Iriqat and Abu Daqar (2017) investigate the impact of CRM on Long-term Customers' Loyalty in the Palestinian Banking Industry, they found that there is a positive relationship between long-term customers' loyalty and CRM, CRM System Integration and Employee's Behavior clarified $48.2 \%$ of the variance in long-term customers' loyalty. Additionally, they clarified that the banks need to periodically update the customers' database. Giannakis and Boutsouki (2014) further attempted to approximate the extent to which CRM effectiveness influence potential for customer engagement, with a specific focus on CRM practices, reflected on the measures of customer performance. The findings show that customer affective commitment and overall gratification with the bank are significant influences of client willingness to deepen their relationship with the financial institution. In addition, the financial institution's presence on social media also has a significant association with client willingness to engage in social CRM with the bank.Muro et al. (2013) investigated the strategic benefits and challenges of utilizing CRM systems in the banking sector, finding that the use of information and communication technologies provided personalized service and attention to bank customers. In addition, the researchers also determined that CRM improves relationships and processes with business partners (B2B) and also with customers. Most importantly, it was noted that CRM builds long-term relationships and loyalty when implemented appropriately and that CRM is beneficial investors, employees, and customers because it enhances performance.

Padmavathy et al. (2012), in turn, examined the effectiveness of customer relationship management in the banking sector, as well as the relationship of CRM and technology-orientation, reliability, process-driven approach, customer experience, and organizational commitment. These latter variables were considered as the important constructs of customer relationship management effectiveness. From the findings, reliability, process-driven approaches, and organizational commitment were identified as three constructs of CRM effectiveness with a positive influence on customer satisfaction; while reliability had a positive effect on both customer loyalty and satisfaction. In this study, the scholar's concentrates on five main CRM dimensions that aligned with other researchers whom investigated in many industries and founded that the following dimensions significantly enhance Customers' Satisfaction, these dimensions are Service Quality, Solving Customers' Problems, Customers' Database, CRM System Integration and Employees Behavior.

Customers' satisfaction plays various important roles in the sustainability and success of business organizations. For example, customer satisfaction provides organizations with a leading measure of customer loyalty; repurchase intentions, and advocacy for the product or organization (Grissemann \& Stokburger-Sauer, 2012; Jacka \& Keller, 2013). Furthermore, organizations may also use customer satisfaction as a point of differentiation in competitive markets especially in promotion activities (Dehgan et al, 2012; Oliver, 2014). Customer satisfaction also increases the lifetime value of customers as it plays a vital role in determining the 
amount of money generated by the customer for the business; while the costs of retaining existing customers is also lower than the cost of acquiring new customers (Sun \& Kim, 2013; Sanjuq, 2014; Saad, 2012). Finally, Customer satisfaction also reduces the potential for negative word of mouth since unsatisfied customers tend to complain about their experience to other potential customers, thus harming the organizations or brand's reputation and sales (Rego et al, 2013; Hill et al., 2013; Kaura, 2013).

Customers' satisfaction in the banking industry has long been considered as a determinant of business performance. Kaur et al. (2012) sought to investigate gap between perceived and expected levels of gratification among banking customers, using t-tests and Gap Analysis technique to analyze questionnaire data collected from bank customers. The results indicated that there is a significant chasm between the perception of gratification and the expectation of gratification among bank customers. This difference was attributed to similar differences between customer perception and customer expectations about banking service quality.

Gazor et al. (2012) also sought to examine the influence of service quality on the satisfaction of customers in the financial service industry, as well as the relationship between service quality perceptions and customer loyalty to financial institution employees and organizations. An analysis of the questionnaire surveys found that financial service quality was the most desirable factors among customers in terms of satisfaction. Further, prompt and effective responses to customer problems were also reported to significantly improve customer satisfaction, as well as customer loyalty to both banking employees and organizations. Rezghi et al. (2014) further investigated the relationship between CRM systems and customer satisfaction in the banking industry of an Islamic country, in this case, Iran, using regression methods and inferential statistics to analyze questionnaire data from bank customers. The findings showed that there was a positive and significant relationship between customer gratification and four constructs of CRM namely the handling of complaints, service access levels, service characteristics, and service quality.

There are several dimensions of customer satisfaction identified in literature including effective response (Kärnä, 2014; Grissemann \& Stokburger-Sauer, 2012), perceived value (Hsu et al., 2012; Rego et al, 2013), and fulfillment of important needs (Steven et al., 2012). Other dimensions of customer satisfaction include fulfilling changing or new customer needs (Steven et al., 2012; Wang, 2013; Graf et al., 2013) and confirmation of beliefs or expectations (Dehgan et al, 2012).

\section{Hypotheses}

H0-1: There is no empirical relationship between CRM dimensions and customers' satisfaction in the banks in North West Bank in Palestine

Ha-1: There is an empirical relationship between CRM dimensions and customers' satisfaction in the banks in North West Bank in Palestine

H0-2: There is no empirical influence of CRM dimensions on customers' satisfaction in the banks in North West Bank in Palestine

Ha-2: There is an empirical influence of CRM dimensions on customers' satisfaction in the banks in North West Bank in Palestine

\section{Methodology}

\subsection{Data Collection and Reliability}

The primary data were used in this paper. The scholars' used the questionnaire to gather data from the banks' employees in Palestine. This survey questionnaire contained three sections, CRM is the first section, it consists of five sub-sections, 1) service quality has 13 items, 2) employee's behavior (6 items), 3) customer's database (7 items), 4) CRM system integration (7 items) and 5) solving customer's problem (12 items). Customers' Satisfaction is the second section which consists of 12 items and the last part is the demographic dimension about the respondents, it consists of 7 variables, the overall items in these sections is 57 except the demographic one. The scholars' used five Likert scale in the questionnaire except for the demographic dimension, the scale is from 5= Strongly Agree, $1=$ Strongly Disagree. The scholars' developed the questionnaire items based on previous literature reviews. In addition, the scholars' calculated the reliability in this study using Cronbach's Alpha equations. It was (0.951) for (CRM), (0.911) (Customers' Satisfaction), in and the total was (0.931).

\subsection{Population and Sample size}

Banks in Palestine have more 7,000 employees. The population in this paper is limited for the operated foreign and local banks in the Northern West Bank employees (around 1,960 employees). The scholar's used the sample size equation to determine the minimum sample size, thus the minimum sample size is 322 employees in the 
targeted banks in Palestine. The simple random sample used by the scholars to meet the study objectives.

\subsection{Conceptual Model}

The main objective of this study is to address the impact of CRM dimensions on customers' satisfaction in the banks in Palestine. It is essential for the banks to enhance and improve a strong relationship with their customers in order to deliver products and services that meet their needs and expectations in order to satisfy them (Winer, 2001). The conceptual framework in this study developed on this framework, CRM dimensions are the key component of Customers' Satisfaction. Figure 1 shows the dependent and independent variables. Subsequently, the scholar's set the conceptual framework to guide the study as the follows in figure 1 .

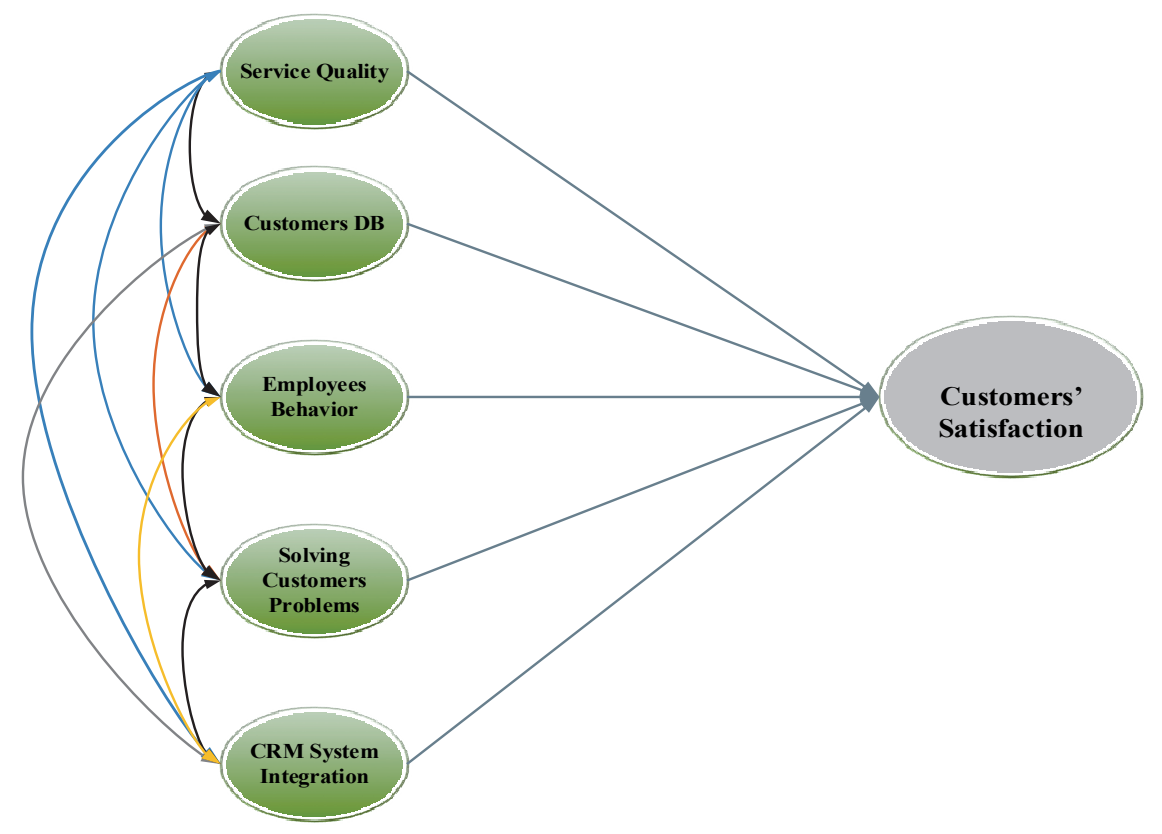

Figure 1. Conceptual Model

Source: own

\section{Data Analysis and Discussion}

The data were analyzed by using the statistical package for Social Sciences (SPSS). The scholars' checked data for entry errors. Pearson correlation was used to analyze the relationship between variables, the multilinear regression in order to test the relationship between the CRM dimensions and customers' satisfaction, also to investigate the significant impact of CRM dimensions on customers' satisfaction.

H0-1: There is no empirical relationship between CRM dimensions and customers' satisfaction in the banks in North West Bank in Palestine

Ha-1: There is an empirical relationship between CRM dimensions and customers' satisfaction in the banks in North West Bank in Palestine

Table 1. Correlation coefficients between CRM dimensions and customers' satisfaction

\begin{tabular}{llllllll}
\hline Dimensions & $\mathbf{1}$ & $\mathbf{2}$ & $\mathbf{3}$ & $\mathbf{4}$ & $\mathbf{5}$ & $\mathbf{6}$ & $\mathbf{7}$ \\
\hline Service Quality & 1 & & & & & & \\
Customers Database & $.683^{* *}$ & 1 & & & & & \\
Employees Behavior & $.520^{* *}$ & $.541^{* *}$ & 1 & & & & \\
Solving Customers Problems & $.725^{* *}$ & $.622^{* *}$ & $.625^{* *}$ & 1 & & & \\
CRM System Integration & $.481^{* *}$ & $.539^{* *}$ & $.358^{* *}$ & $.649^{* *}$ & 1 & & \\
CRM & $.873^{* *}$ & $.819^{* *}$ & $.734^{* *}$ & $.901^{* *}$ & $.723^{* *}$ & 1 & \\
Customers Satisfaction & $.550^{* *}$ & $.585^{* *}$ & $.460^{* *}$ & $.647^{* *}$ & $.701^{* *}$ & $.715^{* *}$ & 1 \\
\hline
\end{tabular}

**. Correlation is significant at the 0.01 level Source: own 
Table 1 shows the Person correlation coefficient between CRM dimensions and customers satisfaction. Findings in above table indicate a significant strong positive relationship between customer relationship management (CRM) and each of its five dimensions (service quality, customer's database, employee's behavior, solving customer's problems, and CRM system integration), $(\mathrm{r}=.873, \mathrm{p}<0.01, \mathrm{r}=.819, \mathrm{p}<0.05, \mathrm{r}=.734, \mathrm{p}<0.01, \mathrm{r}$ $=.901, \mathrm{p}<0.01, \mathrm{r}=.823, \mathrm{p}<0.01)$ respectively. Whereas, it represents a significant strong positive relationship between customers' satisfaction and both of CRM and CRM system integration $(\mathrm{r}=.715, \mathrm{p}<0.01, \mathrm{r}=.701$, $\mathrm{p}<0.01)$. Additionally, there is a significant positive relationship between customers' satisfaction and each of service quality, customer's database, employee's behavior, and solving customer's problems $(\mathrm{r}=.550, \mathrm{p}<0.01, \mathrm{r}$ $=.585, \mathrm{p}<0.01, \mathrm{r}=.460, \mathrm{p}<0.01, \mathrm{r}=.647, \mathrm{p}<0.01)$ respectively.

Based on the above table, the researchers can conclude that: Service Quality plays a significant role in CRM in the banking industry in Palestine. Solving customer's problems is an important pillar for the banks, it is a KPI indicator to measure and analyze that their customers will not leave to other rivals. CRM system integration and customer's satisfaction are a better predictor than employee's behavior of customer's loyalty. The researchers also concluded that service quality wasn't the strongest relationship with long-term customer's loyalty, it is less than the role of customer's satisfaction or CRM system integration; oppositely, employee's behavior dimension has a minor impact on the loyalty which is less than the impact of service quality. According to the reviews for other researchers found that service quality has the significant impact on customer's satisfaction along with solving customer's problems, these two dimensions play the important role in customer's satisfaction that leads to a higher customer's loyalty. Other scholars' results corresponded with the scholar's results as Nazir et al. (2014) investigated the influence of customer relationship management on customer satisfaction, the findings revealed a positive and significant relationship between customer satisfaction and three constructs of customer relationship management namely service features, service access, and service quality. Rezghi et al. (2014) further investigated the relationship between CRM systems and customer's satisfaction in the banking industry, in this case, the findings showed that there was a positive and significant relationship between customer's satisfaction and four constructs of CRM namely the handling of complaints, service access levels, service characteristics, and service quality.

H0-2: There is no empirical influence of CRM dimensions on customers' satisfaction in the banks in North West Bank in Palestine

Ha-2: There is an empirical influence of CRM dimensions on customers' satisfaction in the banks in North West Bank in Palestine

Table 2. R-square and ANOVA for Customers Satisfaction econometrics model

\begin{tabular}{lllllllll}
\hline Model & Sum of Squares & df & Mean Square & F & Sig. & R & R Square & Adjusted R Square \\
\hline Regression & 18.606 & 5 & 3.721 & 50.222 & $.000^{\mathrm{b}}$ & & & \\
Residual & 10.373 & 223 & .074 & & & $.801^{\mathrm{a}}$ & .642 & .629 \\
Total & 28.979 & 228 & & & & & & \\
\hline
\end{tabular}

a. Dependent Variable: Customers Satisfaction

b. Source: own

The researcher results from the above table, by using ANOVA, it shows a significant value of 50.222 for the F-distribution with 5 and 223 df. The F-test taken as a measure of the overall significance of the estimated regression, it indicates that the p-value is less than 0.05 , which indicates that there is a significant relationship exists between the selected variables in this model; in other words indicates that the combination of these variables significantly predicts the dependent variable, also as $\mathrm{R}^{2}=0.642$ which means the independents variables can explain $64.2 \%$ from the variation in dependent variable customers satisfaction, also the multiple correlation coefficient " $\mathrm{R}=0.801$ " shows a positive and strong linear relationship between dependent variable customers' satisfaction and the predictors.

Table 3. The OLS summary statistics of the null hypothesis

\begin{tabular}{|c|c|c|c|c|c|}
\hline \multirow[b]{2}{*}{ Model } & \multicolumn{2}{|c|}{$\begin{array}{l}\text { Unstandardized } \\
\text { Coefficients }\end{array}$} & \multirow{2}{*}{$\begin{array}{l}\text { Standardized } \\
\text { Coefficients } \\
\text { Beta }\end{array}$} & & \multirow[b]{2}{*}{ Sig. } \\
\hline & B & Std. Error & & $\mathbf{t}$ & \\
\hline
\end{tabular}




\begin{tabular}{llllll}
\hline (Constant) & .197 & .443 & & .445 & .657 \\
Service Quality & $\mathbf{. 1 9 1}$ & $\mathbf{. 0 5 8}$ & $\mathbf{. 1 7 0}$ & $\mathbf{3 . 3 0 7}$ & $\mathbf{. 0 0 1}$ \\
Customers Database & .021 & .097 & .016 & .217 & .828 \\
Employees Behavior & .029 & .085 & .027 & .337 & .737 \\
Solving Customers Problems & .004 & .099 & .003 & .042 & .967 \\
CRM System Integration &. $\mathbf{7 2 7}$ & $\mathbf{. 0 4 7}$ & $\mathbf{. 7 8 0}$ & $\mathbf{1 5 . 3 1 9}$ & $\mathbf{. 0 0 0}$ \\
\hline
\end{tabular}

Source: own

The multiple regression analysis was used to test if the CRM dimensions significantly predicted Customers Satisfaction. The results of the regression showed that the two predictors (Service Quality and CRM System Integration) explained $64.2 \%$ of the variance $\left(\mathrm{R}^{2}=0.642, \mathrm{~F}(5,223)=50.222, \mathrm{P}<0.05\right)$. It was found that Service Quality significantly predicted Customers Satisfaction $(\beta=.191=, p=0.001)$, as did CRM System Integration $(\beta=.727=, p=0.000)$.

\section{The econometric model equation:}

\section{Customers satisfaction= 0.191 Service Quality+ 0.727 CRM System Integration.}

\section{The interpretations of the significant independent variables:}

1. There is a direct impact between service quality and customer's satisfaction, and an increased service quality by 10 units may increase the customer's satisfaction by 1.91 units.

2. There is a direct impact between CRM system integrations and customer's satisfaction, and increasing CRM system integrations by 10 units may increase the customer's satisfaction by 7.27 units.

3. No significant impact for these predictor variables (employee's behavior, customers' database, and solving customer's problems) on customer's satisfaction.

The scholar's results show in Hypothesis (2) a significant impact exists between the selected variables in this model, in other words "Indicates that the combination of these variables significantly predicts the dependent variable", $\mathrm{R} 2=0.642$ which means the independents variables can explain $64.2 \%$ from the variation in dependent variable "Customers' Satisfaction", also multiple correlation coefficient " $\mathrm{r}=0.801$ " shows positive and strong linear relationship between dependent variable "Customers' Satisfaction" and the predictors (CRM dimensions).The scholar's results show that only "Service Quality" and "CRM System Integration" are significantly contributing to the equation. When a bank provides a better service quality than others in the market; it means that this bank has more details about the customer's in the market and wants to satisfy their needs and meets their expectations. CRM application will use the well-integrated systems to present the most qualified services for customers once these two dimensions integrated with each other, so customers will be more satisfied in this bank than others.

\section{Conclusion and Recommendations}

This paper aims to address the impact of customer relationship management dimensions on customers' satisfaction in the banks in Palestine, the results of this study showed a significant positive relationship between customers' satisfaction and the CRM dimensions. CRM system integration and service quality explained $64.2 \%$ from the variation in dependent variable Customers' satisfaction.

Banks advised to periodically review its customer's problems and complaints to avoid any similar problems that will be incurred in the future because customers have a high interest in dealing and solving their problems by the banks on time and to avoid similar problems in future, so banks positive reputation is usually very important.

The scholar's recommended to keep the effective communication between CRM and the banks customers due to the high turnover of RM from the banks, so the customers' need an alternative communication channels with their banks because of the absence of the RM which are responsible for handling their transactions, so, banks advised to enhance their online customer service centers, this method will keep an eye on the customers' needs and to track his request orders, so the customer will have a feeling that the bank is following up his orders, this will establish trust channels between the customer and the banks.

\section{References}

Agariya, A. K., \& Singh, D. (2012). crm scale development \& validation in Indian banking sector. Journal of Internet Banking and Commerce, 17(1), 1-21.

Awasthi, P., \& Sangle, S. P. (2013). The importance of value and context for mobile CRM services in banking. 
Business Process Management Journal, 19(6), 864-891

Baran, R. J., \& Galka, R. J. (2013). CRM: The foundation of contemporary marketing strategy. London: Routledge.

Beard, R. (2014, January 20). Clientheartbeat.com Retrieved October 02, 2016, from https://www.clientheartbeat.com/

Cohen, J. (1962). The statistical power of abnormal-social psychological research: A review. Journal of Abnormal and Social Psychology, 65(3), 145-153.

Dehghan, A., Zenouzi, B., \& Albadvi, A. (2012). An Investigation on the Relationship between Service Quality and Customer Satisfaction: In the Case of CCG CO. International Business Research, 5(1), 3-21.

Dowling, G. (2002). Customer Relationship Management: In B2C Markets, Often Less Is More. California Management Review, 44(3), 121-137. https://doi.org/10.2307/41166134

Farquad, M. A. H., Ravi, V., \& Raju, S. B. (2012). Analytical CRM in banking and finance using SVM: A modified active learning-based rule extraction approach. International Journal of Electronic Customer Relationship Management, 6(1), 48-73. https://doi.org/10.1504/IJECRM.2012.046470

Gazor, H., Nemati, B., Ehsani, A., \& Ameleh, K. (2012). Analyzing effects of service encounter quality on customer gratification in banking industry. Management Science Letters, 2(3), 859-868. https://10.5267/j.msl.2011.11.011

Giannakis, C., \& Boutsouki, C. (2014). Customer relationship management in the era of social web and social customer: an investigation of customer engagement in the Greek retail banking sector. Procedia-Social and Behavioral Sciences, 148(2), 67-78. https://doi.org/10.1016/j.sbspro.2014.07.018

Graf, M., Schlegelmilch, B. B., Mudambi, S. M., \& Tallman, S. (2013). Outsourcing of customer relationship management: Implications for customer satisfaction. Journal of Strategic Marketing, 21(1), 68-81. https://doi.org/10.1080/0965254X.2012.734844

Grissemann, U. S., \& Stokburger-Sauer, N. E. (2012). Customer co-creation of travel services: The role of company support and customer satisfaction with the co-creation performance. Tourism Management, 33(6), 1483-1492. https://doi.org/10.1016/j.tourman.2012.02.002

Haridasan, V., \& Venkatesh, D. (2011). CRM Implementation in Indian Telecom Industry - Evaluating the Effectiveness of Mobile Service Providers Using Data Envelopment Analysis. The International Journal of Business Research and Management (IJBRM), 2(3). Retrieved from http://www.amazonaws.com

Hill, N., Brierley, J., \& MacDougall, R. (2013). How to measure customer satisfaction. Burlington, VT, USA: Gower.

Hsu, C. L., Chang, K. C., \& Chen, M. C. (2012). The impact of website quality on customer satisfaction and purchase intention: perceived playfulness and perceived flow as mediators. Information Systems and e-Business Management, 10(4), 549-570. https://10.1007/s10257-011-0181-5

Iriqat, R. A., \& Daqar, M. A. A. (2017). The Impact of Customer Relationship Management on Long-term Customers' Loyalty in the Palestinian Banking Industry. International Business Research, 10(11), 139. Retrieved from https://doi.org/10.5539/ibr.v10n11p139

Ismail, W. K., \& Rasid, S. Z. (2013) Long, C. S., Khalafinezhad, R. Impact of CRM Factors on Customer Satisfaction and Loyalty. Asian Social Science, 9(10). Retrieved from https://doi.org/10.5539/ass.v9n10p247

Jacka, J. M., \& Keller, P. J. (2013). Business process mapping: Improving customer satisfaction. Hoboken, N.J: Wiley.

Kärnä, S. (2014). Analysing customer satisfaction and quality in construction-the case of public and private customers. Nordic Journal of Surveying and Real Estate Research, 2(1), 112-116.

Kaur, G., Sharma, R. D., \& Mahajan, N. (2012). Exploring customer switching intentions through relationship marketing paradigm. International Journal of Bank Marketing, 30(4), 280-302. Retrieved from https://doi.org/10.1108/02652321211236914

Kaura, V. (2013). Antecedents of customer satisfaction: a thesis of Indian public and private sector banks. International Journal of Bank Marketing, 31(3), 167-186. https://doi.org/10.1108/02652321311315285

Khaligh, A., Miremadi, A., \& Aminilari, M. (2012). The Impact of eCRM on Loyalty and Retention of 
Customers in Iranian Telecommunication Sector. International Journal of Business Management, 7(2), 150-162. Retrieved from https://doi.org/10.5539/ijbm.v7n2p150

Khodakarami, F., \& Chan, Y. E. (Khodakarami, F., \& Chan, 2014). Exploring the role of customer relationship management (CRM) systems in customer knowledge creation. Information \& Management, 51(1), 27-42, https://doi.org/10.1016/j.im.2013.09.001

Mohsan, F., Nawaz, M. M., Khan, M. S., Shaukat, Z., \& Aslam, N. (2011). Impact of Customer Satisfaction on Customer Loyalty and Intentions to Switch: Evidence from Banking Sector of Pakistan. International Journal of Business and Social Science, 2(16), 230- 245.

Muro, M. B., Magutu, P. O., \& Getembe, K. N. (2013). The strategic benefits and challenges in the use of customer relationship management systems among commercial banks in Kenya. European Scientific Journal, ESJ, 9(13), 34-49.

Nazir, S., Khan, S., Jamil, R. A., \& Mehmood, Q. S. (2014). Impact of customer relationship management on customer gratification in hoteling industry. Journal of Management Info, 3(1), 84-98.

Oliver, R. L. (2014). Satisfaction: A behavioral perspective on the consumer. London: Routledge.

Padmavathy, C., Balaji, M. S., \& Sivakumar, V. J. (2012). Measuring effectiveness of customer relationship management in Indian retail banks. International Journal of Bank Marketing, 30(4), 246-266, https://doi.org/10.1108/02652321211236888

Peltier, J., Zahay, D., \& Krishen, A. S. (2013). A hierarchical IMC data integration and measurement framework and its impact on CRM system quality and customer performance. Journal of Marketing Analytics, 1(1), 32-48.

Rego, L. L., Morgan, N. A., \& Fornell, C. (2013). Reexamining the market share-customer satisfaction relationship. Journal of Marketing, 77(5), 1-20.

Rezghi i, A., Valmohammadi, C., \& Yousefpoor, J. (2014). The relationship between customer gratification and customer relationship management system; a case thesis of Ghavamin Bank. Industrial and Commercial Training, 46(4), 220-227.

Saad, N. M. (2012). Comparative analysis of customer gratification on Islamic and conventional banks in Malaysia. Asian Social Science, 8(1), 73-88.

Sanjuq, G. (2014). The impact of service quality delivery on customer gratification in the banking sector in Riyadh, Saudi Arabia. International Journal of Business Administration, 5(4), 77-89. Retrieved from https://doi.org/10.5430/ijba.v5n4p77

Steven, A. B., Dong, Y., \& Dresner, M. (2012). Linkages between customer service, customer satisfaction and performance in the airline industry: Investigation of non-linearities and moderating effects. Transportation Research Part E: Logistics and Transportation Review, 48(4), 743-754. https://doi.org/10.1016/j.tre.2011.12.006

Sun, K. A., \& Kim, D. Y. (2013). Does customer satisfaction increase firm performance? An application of American Customer Satisfaction Index (ACSI). International Journal of Hospitality Management, 35, 68-77. https://doi.org/10.1016/j.ijhm.2013.05.008

Vella, J., \& Caruana, A. (2012). Encouraging CRM systems usage: A thesis among bank managers. Management Research Review, 35(2), 121-133. https://doi.org/10.1108/01409171211195152

Wang, M. L. (2013). Implementing CRM in nursing homes: the effects on resident satisfaction. Managing Service Quality: An International Journal, 23(5), 388-409. https://doi.org/10.1108/MSQ- 08-2012-0086

Winer, R. (2001). A framework for customer relationship management. California Management Review, 43(4), 89-105

\section{Copyrights}

Copyright for this article is retained by the author(s), with first publication rights granted to the journal.

This is an open-access article distributed under the terms and conditions of the Creative Commons Attribution license (http://creativecommons.org/licenses/by/4.0/). 